\title{
The effect of blade thickness on microstructure and mechanical properties of ship's sand-cast propeller
}

\author{
Leszek Piaseczny, \\ Krzysztof Rogowski \\ Polish Naval Academy
}

\begin{abstract}
The microstructure and resultant mechanical properties of the MM55 manganese brass applied to ship sand - cast propeller were investigated in relation to the propeller blade section thickness. It was stated that the increase of blade section thickness from $15 \mathrm{~mm}$ to $45 \mathrm{~mm}$ resulted in the increase of the volume fraction of $\alpha$-phase by $5.3 \%$ and that of $\kappa$-phase by $23.7 \%$, the decrease of the volume fraction of $\beta$-phase by $2.9 \%$, the $0.2 \%$ proof stress $R_{0.2}$ by $11.3 \%$, the ultimate tensile strength $R_{m}$ by $5.5 \%$ and the $5.65 \sqrt{\mathrm{S}_{\mathrm{o}}}$ elongation $A_{5}$ by $16.8 \%$.
\end{abstract}

Keywords: blade thickness, microstructure, sand-cast propeller

\section{INTRODUCTION}

The ship propellers range in size from small (below $2 \mathrm{~m}$ in diameter) to large ones (above $5 \mathrm{~m}$ in diameter) [1].

The specimens of most ship propeller castings constitute separately cast test bars with chemical composition and mechanical properties in line with specification for propeller cast material, Fig. 1 and 2. The test bar can be also cast in the form shown by broken line in Fig. 1 [2].
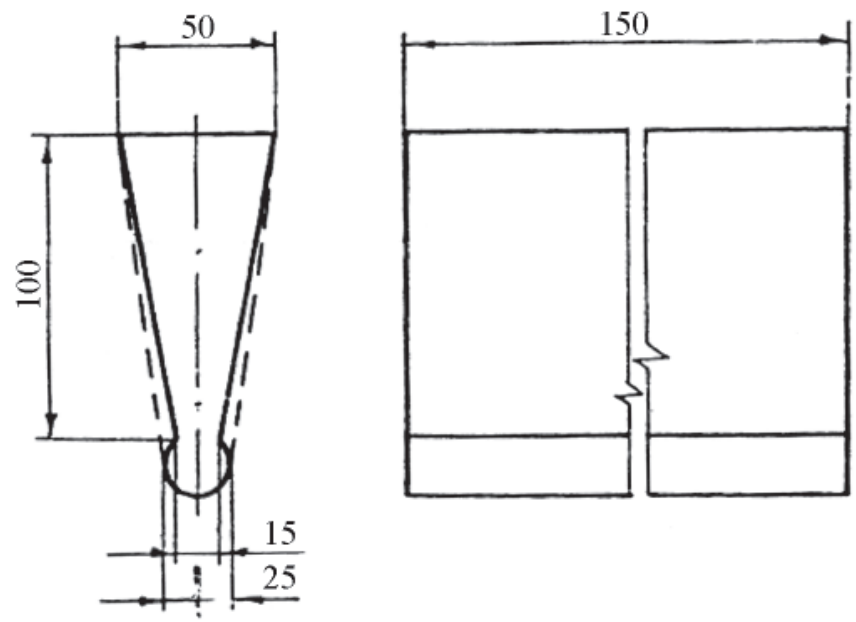

Fig. 1. Separately cast bar for ship's propeller material testing [2]

It is clear that the mechanical properties of the sand-cast ship propeller made of copper alloys, measured on a separately cast test bar, are intended for providing an assessment of general quality of the materials rather than for determination of the actual mechanical properties of the propeller casting, particularly when large sections are involved [3]. In large propeller casting with thick sections slower self-cooling rate is a hindrance from obtaining a microstructure to the effect that the mechanical properties of the propeller casting appear below these obtained from the cast test bar of only $25 \mathrm{~mm}$ diameter [4]. The lowest strength of the propeller casting material was found in the entrance of propeller blade into hub, Fig. 3; which is specially important for constructors [5].

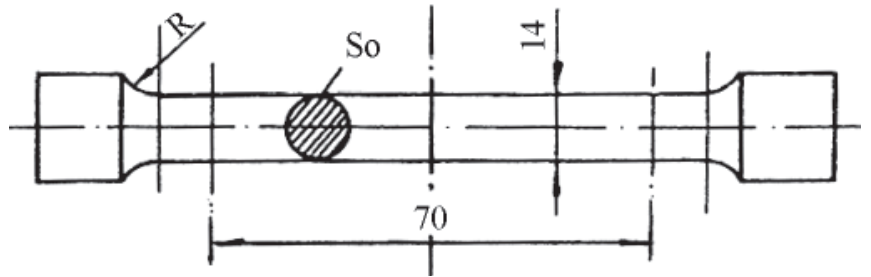

Fig. 2. Test bar for testing mechanical properties [2]
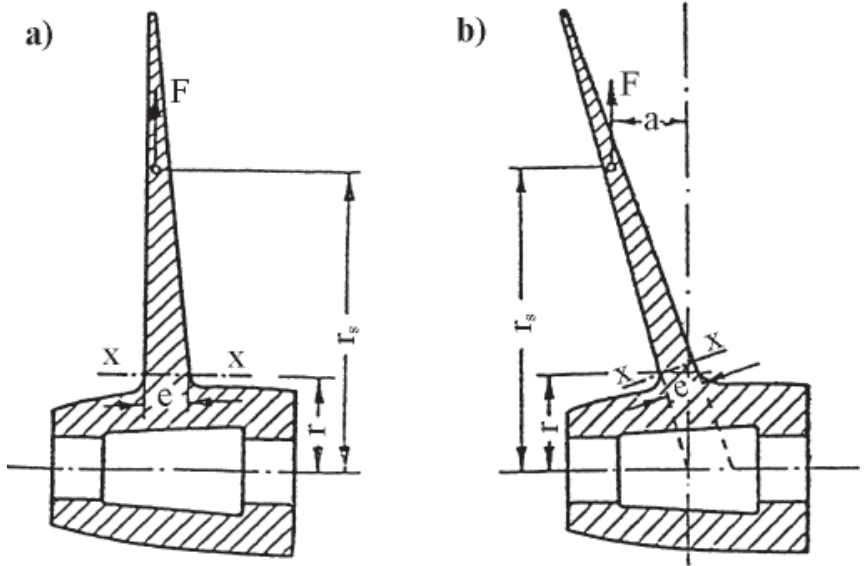

Fig. 3. The propeller blade sections [5]: a) straight blade, b) sloping blade 
The aim of this work is to investigate changes in microstructure and mechanical properties of ship propeller blades along with increasing thickness of their sections.

\section{TESTED MATERIAL AND TESTING PROCEDURES}

The chemical composition and mechanical properties of MM55 manganese brass used for the tested ship's propeller are included in Tab. 1 where also appropriate data taken from PN-91/H-87026 standard [6] and PRS Rules [2] are attached.

The tested ship's propeller blades are $800 \mathrm{~mm}$ long, $15 \mathrm{~mm}$ thick at $0.9 \mathrm{R}$ radius and $45 \mathrm{~mm}$ thick at $0.25 \mathrm{R}$ radius. The samples for testing microstructure and mechanical properties of ships propeller's material were cut out from centre blade section of $15 \mathrm{~mm}, 20 \mathrm{~mm}, 25 \mathrm{~mm}, 35 \mathrm{~mm}$ and $45 \mathrm{~mm}$ in thickness.

also changing, as presented in Tab. 3 and illustrated in Fig. 5 and 6.

Tab. 3. Changes of phase volume fraction in microstructure of MM55 manganese brass used for ship propeller casting, along with the increasing of blade section thickness

\begin{tabular}{|c|c|c|c|}
\hline $\begin{array}{c}\text { Thickness } \\
{[\mathbf{m m}]}\end{array}$ & $\begin{array}{c}\boldsymbol{\alpha} \text { - phase } \\
\text { volume } \\
\text { fraction [\%] }\end{array}$ & $\begin{array}{c}\boldsymbol{\beta} \text {-phase } \\
\text { volume } \\
\text { fraction [\%] }\end{array}$ & $\begin{array}{c}\boldsymbol{\kappa} \text {-phase } \\
\text { volume } \\
\text { fraction [\%] }\end{array}$ \\
\hline 15 & 100 & 100 & 100 \\
\hline 20 & 104.32 & 97.58 & 116.30 \\
\hline 25 & 106.21 & 96.52 & 120.00 \\
\hline 35 & 103.90 & 97.82 & 114.07 \\
\hline 45 & 105.32 & 97.02 & 123.70 \\
\hline
\end{tabular}

Tab. 1. Chemical composition and mechanical properties of the tested MM55 manganese brass used for ship's propeller casting

\begin{tabular}{|c|c|c|c|c|c|c|c|c|c|c|c|}
\hline \multirow{2}{*}{ Item } & \multicolumn{8}{|c|}{ Chemical composition [\%] } & \multirow{2}{*}{$\begin{array}{l}\mathbf{R}_{0.2} \\
\mathbf{M P a}\end{array}$} & \multirow{2}{*}{$\underset{\text { MPa }}{\mathbf{R}_{\mathrm{m}}}$} & \multirow{2}{*}{$\begin{array}{l}\mathbf{A}_{5} \\
\mathbf{\%}\end{array}$} \\
\hline & $\mathrm{Cu}$ & Sn & $\mathrm{Zn}$ & $\mathbf{P b}$ & Mn & $\mathrm{Fe}$ & Al. & $\mathbf{N i}$ & & & \\
\hline $\begin{array}{l}\text { Tested } \\
\text { material }\end{array}$ & 54.5 & - & 41.3 & 0.02 & 3.4 & 1.0 & 0.21 & - & 275 & 488 & 25.6 \\
\hline $\begin{array}{c}\text { Required by } \\
\text { PN-91/H- } \\
87026\end{array}$ & $53-58$ & $\begin{array}{c}\operatorname{Max} \\
0.5\end{array}$ & Balance & $\begin{array}{c}\operatorname{Max} \\
0.5\end{array}$ & $3.6-4.0$ & $0.5-1.5$ & $\begin{array}{c}\operatorname{Max} \\
0.5\end{array}$ & $\begin{array}{c}\text { Max } \\
0.5\end{array}$ & $\begin{array}{l}\text { Min } \\
180\end{array}$ & $\begin{array}{l}\text { Min } \\
450\end{array}$ & $\begin{array}{l}\text { Min } \\
15.0\end{array}$ \\
\hline $\begin{array}{l}\text { Required } \\
\text { by PRS } \\
\text { rules }\end{array}$ & $52-62$ & $\begin{array}{c}\operatorname{Max} \\
1.5\end{array}$ & $35-40$ & $\begin{array}{c}\operatorname{Max} \\
0.5\end{array}$ & $0.5-4.0$ & $0.5-2.5$ & $0.5-3.0$ & $\begin{array}{c}\operatorname{Max} \\
0.5\end{array}$ & 175 & 440 & 20.0 \\
\hline
\end{tabular}

\section{TEST RESULTS AND DISCUSSION}

The results of tensile tests are listed in Tab. 2 .

Tab. 2. Mechanical properties

of MM55 manganese brass used for the tested propeller

\begin{tabular}{|c|c|c|c|c|}
\hline $\begin{array}{c}\text { Blade } \\
\text { thickness } \\
{[\mathbf{m m}]}\end{array}$ & $\begin{array}{c}\mathbf{R}_{\mathbf{0 . 2}} \\
{[\mathbf{M P a}]}\end{array}$ & $\begin{array}{c}\mathbf{R}_{\mathbf{m}} \\
{[\mathbf{M P a}]}\end{array}$ & $\begin{array}{c}\mathbf{A}_{\mathbf{5}} \\
{[\mathbf{\%}]}\end{array}$ & HV20 \\
\hline 15 & 275 & 488 & 25.6 & 177 \\
\hline 20 & 259 & 482 & 25.8 & 171 \\
\hline 25 & 263 & 484 & 23.6 & 165 \\
\hline 35 & 248 & 477 & 23.1 & 149 \\
\hline 45 & 244 & 461 & 21.3 & 146 \\
\hline
\end{tabular}

The results are also graphically shown in Fig. 4.

It can be observed that along with the increasing of blade thickness the ultimate tensile strength $\mathrm{R}_{\mathrm{m}}$ of the blade material decreased initially slowly and then quickly. Similar are the changes of the $5.65 \sqrt{\mathrm{S}_{0}}$ elongation $\mathrm{A}_{5}$ of the material, which become stable when the blade section thickness approaches 45 $\mathrm{mm}$. The $0.2 \%$ proof stress $\mathrm{R}_{0.2}$ and hardness HV20 decreased initially quickly and became stable at the blade section thickness close to $45 \mathrm{~mm}$. All the changes of mechanical properties of propeller's casting material resulted from the decreasing of self-cooling rate of propeller casting along with increasing blade section thickness.

The metalographic examinations showed that with the increasing of the blade section thickness the microstructure of the manganese brass used for the propeller casting was

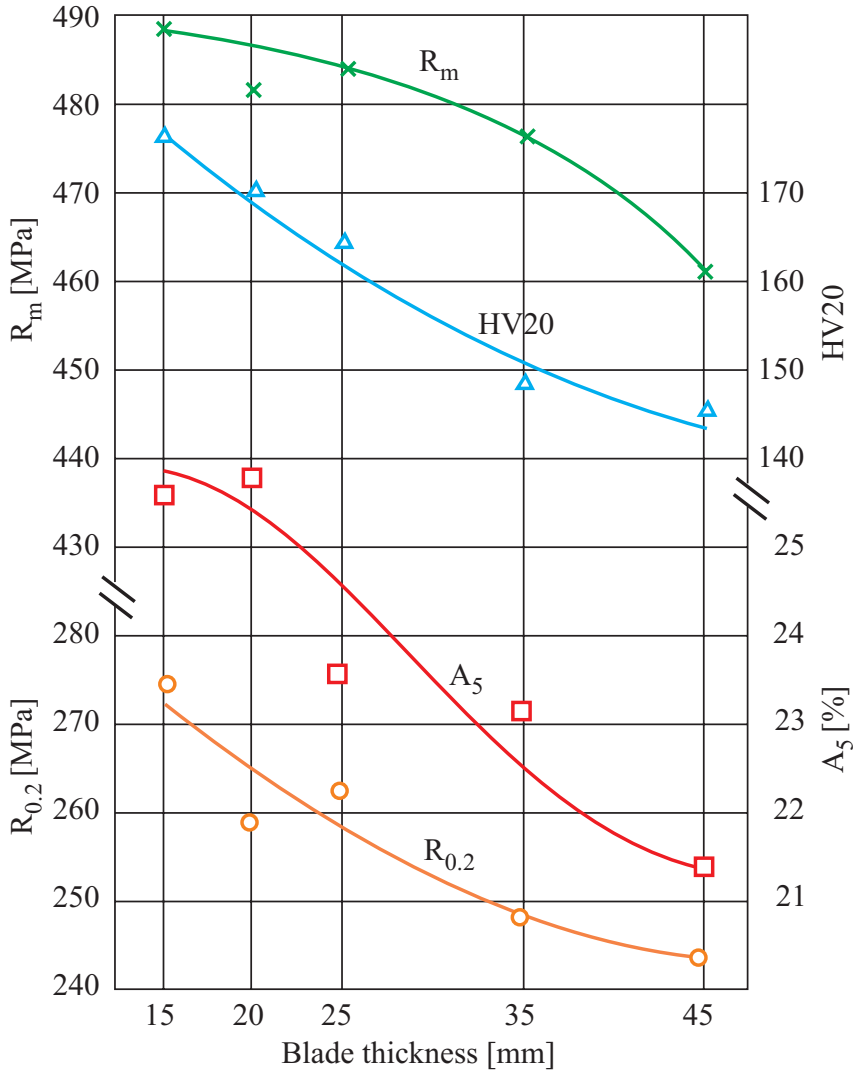

Fig. 4. Changes of mechanical properties of MM55 manganese brass used for ship propeller casting in function of increasing blade section thickness

The increase of the blade section thickness resulted not only in the volume fraction of the phase in microstructure but also in the increased areas of $\alpha$-phase precipitates. Fig. 7 
shows the number of $\alpha$-phase precipitates in relation to thickness of propeller blade section. It can be observed that in the microstructure the number of precipitates of $0-500 \mu \mathrm{m}^{2}$ area diminished and that of precipitates of 1001-5000 $\mu^{2}$ are increased along with decreasing self-cooling rate.

The course of microstructure changes in MM55 manganese brass used for ship propeller casting resulted from the decreasing of self-cooling rate of casting along with the increasing of blade section thickness.

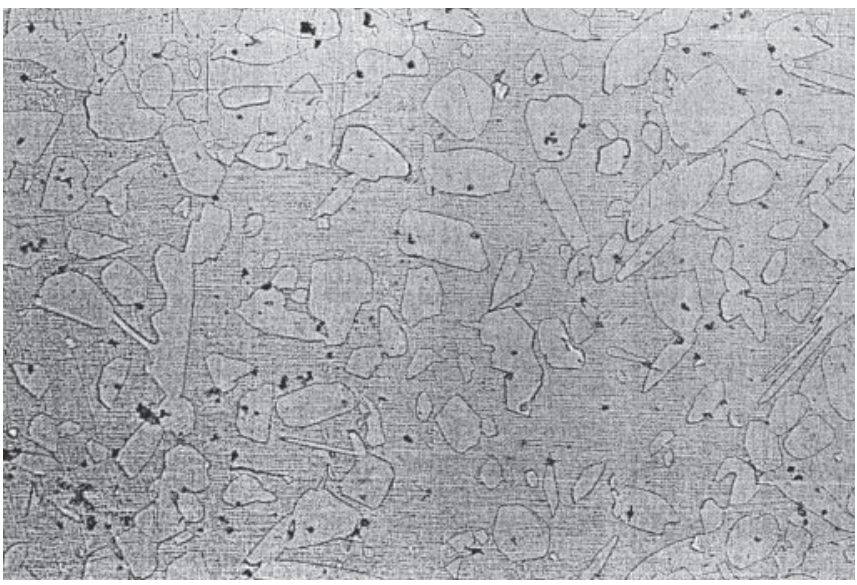

Fig. 5. Micrograph of MM55 manganese brass used for ship propeller casting, at the blade section of $15 \mathrm{~mm}$ in thickness. Magnification : $240 x$.

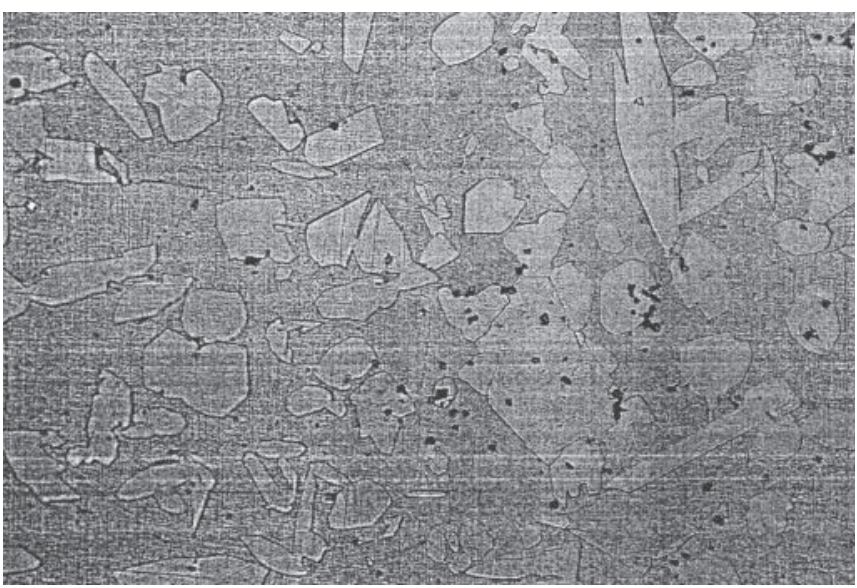

Fig. 6. Micrograph of MM55 manganese brass used for ship propeller casting, at the blade section of $45 \mathrm{~mm}$ in thickness. Magnification : $240 x$

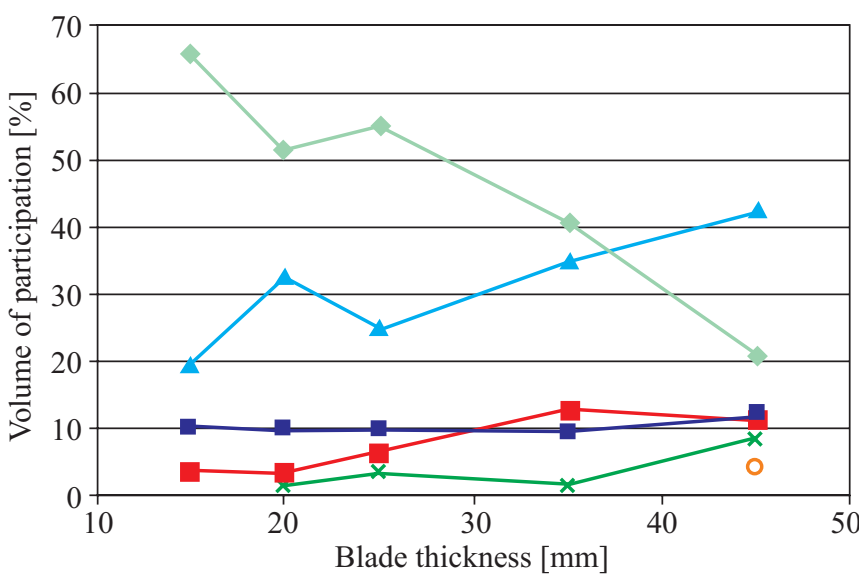

$\longrightarrow 0-500 \quad \rightarrow-501-1000 \quad \rightarrow-1001-5000$
$\rightarrow 500110000 \rightarrow x-10001-50000 \quad-50001-100000$

Fig. 7. Volume of precipitation in relation to thickness of ship propeller blade section

\section{CONCLUSIONS}

The performed tests showed that the increasing - from 15 $\mathrm{mm}$ to $45 \mathrm{~mm}$ - of blade section thickness of the ship sand - cast propeller made of MM55 manganese brass resulted in :

An increase of the volume fraction of hard and short $\kappa$ - phase in the material's microstructure, and a simultaneous decrease of the mechanical properties of the material.

The following decrease of particular properties was observed : the $0.2 \%$ proof stress $\mathrm{R}_{0.2}-$ by $5.3 \%$, the ultimate tensile strength $\mathrm{R}_{\mathrm{m}}$-by $5.5 \%, 5.65 \sqrt{\mathrm{S}_{\mathrm{o}}}$ elongation $\mathrm{A}_{5}$ - by $16.8 \%$, and HV20 hardness - by $17.5 \%$.

\section{BIBLIOGRAPHY}

1. Meyne K.: Propellerfertigung-PropellerwerkstoffePropellerfestigkeit. Schiff u. Hafen, Jg. 26, H. 3, 1974

2. Polish Register of Shipping : Rules for the construction and classification of sea-going ships, Part 13, Materials (in Polish), Gdańsk 2002

3. Wenschot P.: The properties of Ni-Al bronze sand cast ship propeller in relation to section thickness. Naval Engineers Journal, September 1986

4. Couture A.: Literature survey on the properties of cast Ni-Al and $\mathrm{Mn}-\mathrm{Ni}$-Al bronzes. AFS International Cast Metal Journal, June 1981

5. Ruseckij A.A., Žučenko M.M., Dubrovin O.V.: Sudovyje dvižiteli (in Russian) Sudostroenie. Leningrad 1971

6. PN-91/H-87026 Polish standard : Cu-alloys for casting. Kinds (in Polish), Warszawa 1991.

\section{CONTACT WITH THE AUTHORS}

Prof. Leszek Piaseczny

Mechanic-Electric Faculty,

Polish Naval University

Śmidowicza 69

81-103 Gdynia, POLAND

e-mail : 1pias@amw.gdynia.pl

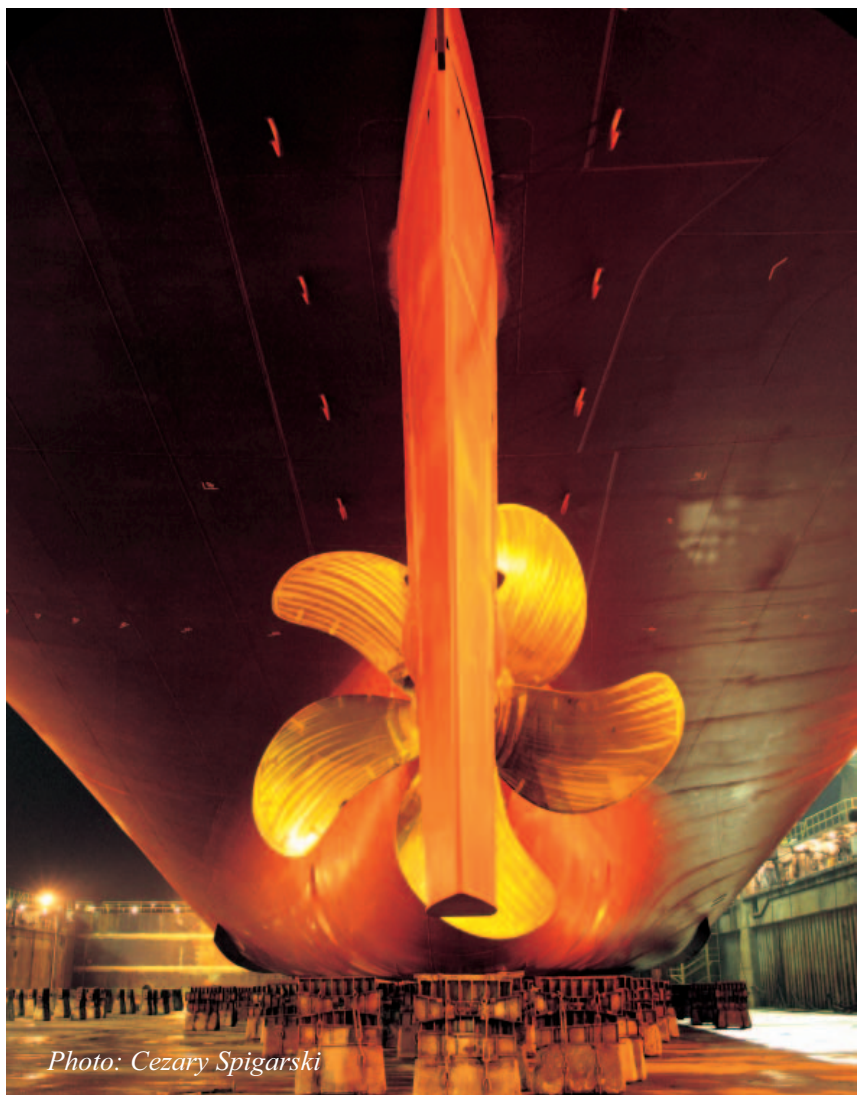

